\author{
Maciej Kołodziejski
}

\title{
NADZÓR I KONTROLA BISKUPA DIECEZJALNEGO NAD ADMINISTRATORAMI DANYCH W DIECEZJI (ANALIZA NA PODSTAWIE PRZYKŁADU PARAFII)
}

Przedmiotem artykułu jest zakres dyscypliny, jaką posiada biskup diecezjalny poprzez nadzór i kontrolę nad administratorami danych we własnej diecezji. Zgodnie z art. 40 ust. 1 Dekretu KEP z dnia 13 marca 2018 r. ${ }^{1}$ „niezależnie od monitorowania i zapewniania przez Kościelnego Inspektora Ochrony Danych przestrzegania przepisów w zakresie ochrony danych osobowych w rozumieniu art. 35 ust. 1 niniejszego Dekretu, do biskupa diecezjalnego $\mathrm{w}$ ramach zwyczajnych działań kontrolnych (np. podczas wizytacji kanonicznych) należy także nadzór nad prawidłowym przestrzeganiem przepisów dotyczących pozyskiwania, przechowywania i przetwarzania danych osobowych".

Zgodnie z Dekretem administratorami danych są kościelne publiczne osoby prawne. W strukturach diecezjalnych - według ustawy z dnia 17 maja 1989 r. o stosunku Państwa do Kościoła Katolickiego w Rzeczypospolitej Polskiej ${ }^{2}$ - z mocy samego prawa osobami prawnymi, poza diecezją, są: parafie, kościoły rektoralne, Caritas diecezji i Papieskie Dzieła Misyjne. Biskup diecezjalny co do kościelnych publicznych osób prawnych w ramach

KS. MGR LIC. MACIEJ KOŁODZIEJSKI, DOKTORANT - Szkoła Doktorska, Uniwersytet Kardynała Stefana Wyszyńskiego w Warszawie; e-mail: kmaciu@wp.pl; https://orcid. org/0000-0002-8972-2709

${ }^{1}$ Dekret ogólny $w$ sprawie ochrony osób fizycznych $w$ związu z przetwarzaniem danych osobowych w Kościele Katolickim (13.03.2018), „Akta Konferencji Episkopatu Polski” 30 (2018), s. 31-45 [dalej cyt.: Dekret].

${ }^{2}$ Dz. U. z 2018 r., poz. 380 z późn. zm. 
wykonywanej przez nie działalności wewnętrznej, tzn. 1) „w swoim zakresie” [Banaszak 2012], „w swojej dziedzinie” [Krukowski 2008, 95-96], i „swoich spraw” (art. 2 ustawy) posiada nieskrępowaną możliwość kontroli w ramach wykonywanej przez siebie władzy pasterskiej. Jednostką przetwarzającą dane diecezji jest kuria, dla której powinien być wyznaczony inspektor ochrony danych. Działania kontrolne w zakresie właściwego przetwarzania danych wykonywane $\mathrm{w}$ imieniu biskupa diecezjalnego należą, zgodnie z art. 32 pkt 2 Dekretu, do inspektora: „monitorowanie przestrzegania niniejszego dekretu oraz polityk administratora lub podmiotu przetwarzającego $\mathrm{w}$ dziedzinie ochrony danych osobowych, w tym podział obowiązków, działania zwiększające świadomość, szkolenia personelu uczestniczącego $\mathrm{w}$ operacjach przetwarzania oraz powiązane $\mathrm{z}$ tym audyty”. Inspektor ochrony danych w diecezji jest swego rodzaju „wikariuszem biskupim" dla nadzoru i kontroli właściwej kultury przetwarzania danych. Do jego zadań i obowiązków należy zwyczajna kontrola w tym zakresie wykonywana w imieniu biskupa dla wszystkich podmiotów przetwarzających w diecezji.

Ponadto wszyscy administratorzy w diecezji mają możliwość wyznaczenia inspektora, który w ramach właściwych sobie kompetencji będzie czuwał nad polityką danych administratora w relacji $\mathrm{z}$ inspektorem powołanym dla całej diecezji, dlatego warto poświęcić temu osobną refleksję. $\mathrm{Na}$ szczególną uwagę, w ramach działalności pasterskiej biskupa (w tym kontroli i nadzoru), zasługuje parafia jako administrator danych oraz urząd proboszcza jako podmiot przetwarzający. Działania kontrolne wykonywane przez biskupa wobec jednostki parafialnej mogą stanowić swego rodzaju „model” właściwego przetwarzania dla pozostałych administratorów.

\section{WIZYTACJA KANONICZNA}

Zgodnie z Kodeksem Prawa Kanonicznego z 1983 r. ${ }^{3}$ biskup diecezjalny ma obowiązek wizytowania diecezji każdego roku w całości lub w części, tak jednak, aby w ciągu pięciu lat zwizytował całą diecezję. Co do zasady

${ }^{3}$ Codex Iuris Canonici auctoritate Ioannis Pauli PP. II promulgatus (25.01.1983), AAS 75 (1983), pars II, s. 1-317; tekst polski: Kodeks Prawa Kanonicznego, przekład polski zatwierdzony przez Konferencję Episkopatu, Pallottinum, Poznań 1984 [dalej cyt.: KPK/83]. 
obowiązek wizytacji biskup powinien spełniać osobiście, lecz gdy zaistnieje prawna przeszkoda, może to czynić przez biskupa koadiutora lub biskupa pomocniczego, ewentualnie przez wikariusza generalnego, biskupiego, rejonowego bądź przez innego kapłana (kan. 396 § 1) [Pawluk 2010, 172]. Wizytacja daje biskupowi możliwość sprawdzenia i rozważenia rzeczywistej działalności i skuteczności struktur dla pełnienia właściwej misji duszpasterstwa. Z okazji wizytacji parafialnej należy m.in. skontrolować stan ksiąg parafialnych oraz innych instytucji jak również sprawdzić administrowanie majątkiem kościelnym. Co do zasady biskup czynności te powierza odpowiedniemu kapłanowi, zwłaszcza dziekanowi, które są wykonywane przed lub po wizytacji [tamże, 173-74]. Najważniejszą czynnością z punktu widzenia ochrony danych osobowych będzie kompleksowa kontrola stanu kancelarii parafialnej, zwłaszcza ksiąg i dokumentów, w których dane są przetwarzane. Do najbardziej istotnych czynności i zadań do podjęcia przez administratorów w zakresie ochrony danych osobowych (w tym wypadku parafii) należą, jeśli chodzi o dokumentację: 1) rejestr czynności przetwarzania, 2) instrukcja postępowania $\mathrm{w}$ sytuacji naruszenia ochrony danych, 3) rejestr naruszenia ochrony danych, 4) polityka bezpieczeństwa danych (diecezja i większe ośrodki parafialne przetwarzające dane na większą skalę), 5) instrukcja zarządzania systemem informatycznym, 6) ewidencja osób upoważnionych do przetwarzania danych, 7) instrukcja dotycząca realizacji praw osób, których dane dotyczą. Jeśli chodzi o procedury do najważniejszych należą: 1) nadanie pisemnych upoważnień do przetwarzania danych, 2) odebranie od upoważnionych osób pisemnych zobowiązań do zachowania tajemnicy, 3) określenie kręgu podmiotów przetwarzających i zawarcie z nimi umów powierzenia przetwarzania danych, 4) ustalenie zakresu obowiązków związanych z ochroną danych (np. w diecezji ekonom), 5) opracowanie i wdrożenie procedur dotyczących kluczy, haseł, stosowania „polityki czystego biurka”, 6) ustalenie zasad wydawania dokumentów z danymi osobowymi osobom trzecim, 7) opracowanie i wdrożenie procedur obiegu dokumentów (np. instrukcja kancelaryjna, dołączenie aneksu do regulaminu wewnętrznego kurii). Ponadto dostosowanie monitoringu do przepisów o ochronie danych osobowych, w szczególności oznaczenie obszaru objętego monitoringiem, sprawdzenie jego adekwatności zastosowania i regulaminu. Konieczna jest również kontrola wprowadzonych zabezpieczeń fizycznych, organizacyjnych i technologicznych. Jeżeli parafia posiada własnego inspektora ochrony 
danych, sprawdzenie, czy doskonali własne kwalifikacje, np. poprzez szkolenia. Obowiązkowym punktem powinien być przegląd strony internetowej pod kątem ochrony danych osobowych wraz z informacją dotyczącą m.in. udzielania informacji i zgłaszania naruszeń wraz z łatwym dostępem kontaktowym do Inspektora Ochrony Danych. W obowiązku informacyjnym, czy to na stronie parafialnej, czy bezpośrednio w kancelarii, należy zwrócić szczególną uwagę na warstwowe informowanie (kto jest administratorem i jak dane są przetwarzane oraz gdzie można znaleźć informacje szczegółowe $)^{4}$.

Podczas wizytacji parafii biskup winien wysłuchać i zapoznać się ze sprawozdaniem stanu parafii. W ramach działań kontrolnych warto w formularzach przedwizytacyjnych umieścić odpowiednią część z pytaniami dotyczącymi właściwego przetwarzania danych przez parafię. W formularzu powinny znaleźć się przynajmniej najważniejsze czynności i zadania, do których zobowiązany jest administrator, a które jako konieczne i szczególnie zalecane wymienia Kościelny Inspektor Ochrony Danych, tj. w zakresie dokumentacji: 1) rejestr czynności przetwarzania, 2) instrukcja postępowania w sytuacji naruszenia ochrony danych, 3) rejestr naruszenia ochrony danych; w zakresie procedur: 1) nadanie pisemnych upoważnień do przetwarzania danych, 2) odebranie od upoważnionych osób pisemnych zobowiązań do zachowania tajemnicy, 3) określenie kręgu podmiotów przetwarzających i zawarcie z nimi umów powierzenia przetwarzania danych, jak również oznaczenie obszaru objętego monitoringiem oraz kontrola wprowadzonych zabezpieczeń fizycznych i technologicznych ${ }^{5}$. Ponadto należy w formularzu zapytać, czy osoby pracujące w kancelarii parafialnej posiadają upoważnienia do przetwarzania danych oraz $\mathrm{w}$ jakim zakresie (księgi, dane cyfrowe), a także, kto posiada dostęp do kancelarii parafialnej w ogóle. Należy również zapytać, czy w przypadku naruszenia ochrony danych osobowych, administrator posiada przynajmniej podstawową wiedzę, w jaki sposób zgłaszać naruszenia ochrony danych osobowych Kościelnemu Inspektorowi Danych Osobowych oraz innym podmiotom (w tym

\footnotetext{
${ }^{4}$ Podręcznik ochrony danych osobowych w Kościele Katolickim. Komentarze, wyjaśnienia, wzory $i$ wskazówki dla administratorów danych osobowych oraz inspektorów ochrony danych publicznych kościelnych osób prawnych (głownie parafii) opracowane przez Kościelnego Inspektora Ochrony Danych. Wersja 3, https://opoka.org.pl/biblioteka /T/TA/TAI/KIODO/podrecznik2018-01.html [dostęp: 17.02.2021], s. 16-20.

5 Tamże.
} 
Nadzór i kontrola biskupa diecezjalnego nad administratorami danych 179

organom ścigania), a jeżeli wystąpiły takie przypadki, czy posiada rejestr takich czynności.

Łaciński termin visito, -are oznacza: odwiedzać, zjawiać się, pokazywać, dać się widzieć, oglądać, wizytować, wyświadczać łaskę, wspierać, ale także doświadczyć i karać [Jougan 1992, 736; Sondel 1997, 997-98]. Wizytacje nazywano kanonicznymi, ponieważ nie odbywały się one w sposób dowolny, lecz według określonych kanonów prawa kościelnego. Zatem pozostają zawsze okazją do rewizji aktualnego stanu rzeczy i poprawy tego, co jeszcze nie domaga w poszczególnej wspólnocie, również w sprawie właściwej kultury przetwarzania danych.

\subsection{Wizytacja instytutów życia konsekrowanego i stowarzyszeń życia apostolskiego}

Zgodnie z art. 40 pkt 2 Dekretu „w instytutach życia konsekrowanego i stowarzyszeniach życia apostolskiego nadzór, o którym mowa w ustępie poprzedzającym, sprawuje wyższy przełożony”. Ustawodawca w KPK/83 stanowi: „członków instytutów zakonnych na prawie papieskim i ich domy biskup może wizytować tylko w przypadkach przewidzianych przez prawo" (kan. 397 § 2). Powszechne prawo kościelne zapewnia instytutom w zakresie dyscypliny wewnętrznej, a więc także i wizytacji kanonicznych, słuszną autonomię, którą ordynariusze miejsca winni nie tylko zachowywać, ale i jej strzec. Dlatego też w większości instytutów wizytacje należą do obowiązków przełożonych wewnętrznych. Jednak w tych instytutach, które niedawno powstały, rozwijają się i pozostają na prawie diecezjalnym, a więc są pod szczególną opieką biskupa diecezjalnego, wizytacje przeprowadzają biskupi tych diecezji, na terenie których znajdują się domy danego instytutu. Biskup diecezjalny w rozumieniu kan. $134 \S 3$ może to prawo delegować także na innych, zwłaszcza wikariuszy od spraw zakonnych. Biskupi lub ich delegaci w czasie swych pasterskich wizytacji w parafiach, a także w sytuacjach koniecznych, mogą wizytować kościoły i kaplice uczęszczane stale przez wiernych oraz szkoły i inne dzieła religijne lub miłosierdzia duchowego, prowadzone przez zakonników niezależnie od tego, czy są członkami instytutów na prawie diecezjalnym czy papieskim. Wizytacji biskupa nie podlegają natomiast szkoły, do których uczęszczają wyłącznie alumni instytutu. Gdyby przy okazji wspomnianych wizytacji biskup wykrył nadużycia, powinien powiadomić o nich przełożonego, a jeśli to nie odniosłoby skutku, sam własną powagą zobowiązany jest 
załatwić sprawę. Podobnie też biskup jest uprawniony i ma obowiązek wizytować w zakresie dyscypliny zakonnej klasztory niezależne (sui iuris) podlegające jedynie przełożonemu klasztoru i poza nim nie mają innego wyższego przełożonego ani też nie są złączone z jakimś instytutem zakonnym tak, że przełożony tego instytutu miałby ustaloną przez konstytucje władzę nad tym klasztorem [de Paolis 2010, 376-77; Gambari 1995, 65960; Zubert 1990, 83-86].

Jest zasadą, że dzieła, które zostały powierzone zakonnikom przez biskupa diecezjalnego podlegają jego władzy i kierownictwu. Osoby zakonne podlegają władzy biskupa w sprawach dotyczących duszpasterstwa, publicznego wykonywania kultu publicznego i innych dzieł apostolskich (kan. $681 \S 1$ ). Biskup diecezjalny podczas wizytacji parafii powierzonej instytutowi zakonnemu posiada pełny nadzór i kontrolę dotyczącą przetwarzania danych osobowych, podobnie jak w parafiach własnej diecezji. Pozostają więc aktualne wszystkie punkty dotyczące właściwego przetwarzania danych jak w punkcie powyżej. Istotną różnicą będzie np. kwestia powołania Inspektora Ochrony Danych. Zgodnie z art. 30 Dekretu, jeżeli przetwarzanie odbywa się na dużą skalę, inspektor powinien być wyznaczony. A zatem, jeśli parafia zakonna przetwarza dane na dużą skalę, biskup wręcz powinien wymagać powołania Inspektora, wraz ze sprawdzeniem jego kompetencji i właściwego działania. W sprawach jedynie wewnętrznych instytutów zakonnych, Inspektor może zostać powołany przez wyższego przełożonego i podlega jego jurysdykcji oraz pozostaje $\mathrm{w}$ relacji urzędowej do Kościelnego Inspektora Ochrony Danych.

\subsection{Wizytacja dziekańska}

Biskup diecezjalny w sposobie nadzoru i kontroli parafii pozostających w granicach jego diecezji może posługiwać się instytucją wikariusza rejonowego, zwanego również dziekanem albo archiprezbiterem (kan. $553 \S 1$ ), albo jeszcze inaczej (np. wikariuszem zewnętrznym czy okręgowym). Jest to kapłan, który stoi na czele wikariatu rejonowego (dekanatu) ${ }^{6}$. Misja dziekana, bliskiego współpracownika biskupa w posłudze duszpasterskiej, ma głównie znaczenie duszpasterskie. Do dziekana należy koordynowanie działalności pastoralnej w jego okręgu. Ma on poznawać i oceniać religijno-

${ }^{6}$ Poprzedni Kodeks używał tylko terminu vicarius foraneus, chociaż wprowadził także jako równorzędne pojęcia dekanatu i archiprezbiteratu (kan. 217) [Sztafrowski 1992, 30]. 
-moralny stan życia parafii, pracę duszpastersko-apostolską, realizację dekretów powizytacyjnych i całokształt spraw administracyjno-gospodarczych [Sztafrowski 1992, 48]. W sposób szczególny te dwa ostatnie aspekty wizytacji dziekańskiej mogą mieć duże znaczenie w kontekście ochrony danych w danej diecezji i stanowić właściwą sobie pomoc dla biskupa co do prawidłowej kultury przetwarzania danych w powierzonym mu Kościele partykularnym. Aby dziekan mógł wypełnić swoje obowiązki przewidziane w kan. $555 \S 1$, powinien wizytować parafie swego obwodu w sposób określony przez biskupa diecezjalnego (kan. 555 § 4). Trzeba zauważyć, że znacząca przestrzeń obejmująca obowiązki i uprawnienia związane z urzędem dziekana, tak ważnym w strukturze Kościoła partykularnego, w KPK/83 została pozostawiona do regulacji prawu partykularnemu, które ma określić i uzupełnić ogólne wytyczne podane w Kodeksie, zgodnie z tradycją i potrzebami duszpasterskimi poszczególnego Kościoła partykularnego. Konsekwentnie ustawodawstwo partykularne poprzez statuty i instrukcje winno doprecyzować przepisy dotyczące wizytacji dziekańskiej.

Ponieważ kodyfikacja z 1983 r. traktuje o wizytacji dziekańskiej bardzo ogólnie i jedynie pośrednio wskazuje na jej przedmiot, odsyłając po szczegóły do prawa partykularnego, powstaje pytanie: w jaki sposób wizytacja dziekańska może w sposób istotny stać się pomocą w zakresie dyscypliny biskupiej dotyczącej ochrony danych?

Wizytacja dziekańska, jak każda wizytacja, musi zawierać w sobie element (bardziej wymiar) kontroli, co nie sprzeciwia się jej wymiarowi duszpasterskiemu? ${ }^{7}$. Prawodawca kodeksowy jasno wskazuje, że dziekan ma prawo i obowiązek „czuwać nad tym, by święte czynności były sprawowane zgodnie z przepisami liturgicznymi, by czystość i piękno kościoła oraz sprzętu liturgicznego, zwłaszcza w sprawowaniu i przechowywaniu Najświętszego Sakramentu były starannie utrzymywane; żeby księgi parafialne były właściwie spisywane i należycie przechowywane, dobra kościelne prawidłowo administrowane, a budynek parafialny otoczony właściwą

\footnotetext{
${ }^{7} \mathrm{Na}$ wymiar duszpastersko-kontrolny wizytacji dziekańskiej zwraca uwagę Kongregacja ds. Biskupów w instrukcji Ecclesiae imago: „należy przywiązywać wielkie znaczenie do funkcji dziekańskiej, którą trzeba uznać za funkcję duszpasterską, a nie tylko prawną, administracyjną i ponadparafialną. Na dziekanie bowiem ciąży nie tylko obowiązek czuwania, lecz obowiązek prawdziwej apostolskiej troskliwości”, zob. Kongregacja ds. Biskupów, Instrukcja na temat pasterskiej posługi biskupów Ecclesiae imago (22.02.1973), w: Ustrój hierarchiczny Kościoła. Wybór źródeł, red. i oprac. W. Kacprzyk, M. Sitarz, Wydawnictwo KUL, Lublin 2006, s. 403-516, nr 187.
} 
troską". Wymienione obowiązki i prawa są wyrazem czuwania, a czuwanie przejawia się w kontroli (kan. $555 \S 1$ ). Ustawodawca kodeksowy nakazuje, aby biskup wizytował parafie przynajmniej co 5 lat, dziekan natomiast wizytuje na ogół częściej (przeważnie raz na rok). Ponadto odpowiada za realizację dekretów powizytacyjnych i całokształt spraw administracyjnych. Większa częstotliwość wizytacji stwarza większą możliwość kontroli, również w zakresie ochrony danych osobowych tych administratorów, którzy są na terenie jego terytorium. Wydaje się zatem słuszne wprowadzenie do prawa partykularnego obowiązku kontroli administracji poszczególnych parafii dekanatu w zakresie właściwego przetwarzania danych dla dziekana, co może pomóc w szybszym rozwiązywaniu niektórych naruszeń. Dodatkowo dziekan mógłby w imieniu biskupa pełnić kontrolę nie tylko nad parafiami własnego terytorium, ale również nad strukturami podobnymi do dekanatu (dekanaty personalne, obrządkowe, funkcyjne) ${ }^{8}$, jak również nad innymi administratorami, jak szkoły katolickie, papieskie dzieła misyjne czy Caritas diecezjalna $\mathrm{z}$ siedzibą w granicach dekanatu. Pozostając $\mathrm{w}$ stałej łączności $\mathrm{z}$ inspektorem ochrony danych $\mathrm{w}$ diecezji, dziekan nie tylko mógłby zgłaszać ewentualne naruszenia czy trudności, ale również postulować pewne rozwiązania dla prawa partykularnego w diecezji w zakresie ochrony danych oraz czuwać nad właściwym wdrożeniem niedociągnięć $\mathrm{w}$ zakresie przetwarzania danych $\mathrm{u}$ administratorów, np. po wizytacji biskupiej. Z kolei rada dziekanów jako organ kolegialny byłaby nieodzowną pomocą dla stworzenia kompleksowych rozwiązań na gruncie diecezji w zakresie ochrony danych osobowych.

Wikariusz zewnętrzny ma możliwość szczegółowego zapoznania się ze zbiorami danych będących na terenie jego okręgu. Nie chodzi tu jedynie o prowadzenie ksiąg metrykalnych, ale również dokumentów i materiałów o znaczącej wartości historycznej. Ponadto mógłby zaproponować pewne wskazówki dla parafii, które korzystają np. z jednego cmentarza, a każda $\mathrm{z}$ nich prowadzi osobną księgę zmarłych, czy archiwizacji dokumentów $\mathrm{w}$ tajnym archiwum.

Zgodnie z art. 30 pkt 2 Dekretu: „Kilka kościelnych publicznych osób prawnych może wyznaczyć jednego inspektora ochrony danych, o ile będzie można łatwo nawiązać z nim kontakt z każdej jednostki organizacyj-

${ }^{8}$ Congregazione per i Vescovi, Direttorio per il ministero pastorale dei vescovi Apostolorum Successores (22.02.2004), w: Ustrój hierarchiczny Kościoła. Wybór źródet, s. $517-711, \mathrm{nr} 218$. 
nej”. W parafiach dekanatu dziekan byłby najwłaściwszą osobą, która mogłaby zaproponować dla kilku administratorów jednego inspektora ochrony danych, oraz dla ośrodków, które przetwarzają dane na dużą skalę, wyegzekwować obowiązek posiadania inspektora.

\section{POSTĘPOWANIE PRZY USUWANIU PROBOSZCZÓW W KONTEKŚCIE PRZETWARZANIA DANYCH OSOBOWYCH}

Biskup diecezjalny w powierzonej sobie diecezji posiada środki administracyjne pozwalające $\mathrm{w}$ określonych przepisami prawa przypadkach wszcząc procedurę usunięcia proboszcza (kan. 1741). Oprócz procedury usunięcia istnieje również procedura przeniesienia (kan. 1748), ale ma ona bardziej wymiar duszpasterski i tym różni się od procedury usunięcia, że w wypadku przeniesienia można tego dokonać, mimo jego owocnej pracy. Usunięcie zaś jest następstwem stwierdzenia, że posługa proboszcza jest bezowocna i szkodliwa [Pawluk 2016, 395] i na tym poprzestaniemy co do właściwego przetwarzania danych przez proboszcza jako „podmiot przetwarzający".

Ustawodawca stwierdza: „Jeśli posługa jakiegoś proboszcza wskutek jakiejś przyczyny, nawet bez jego ciężkiej winy, staje się szkodliwa lub co najmniej bezowocna, proboszcz ten może być usunięty z parafii przez biskupa diecezjalnego" (kan. 1740). Biskup powierza parafię na stałe, jednak stabilność proboszcza nie ma charakteru bezwzględnego. Przyczyny szkodliwej i bezowocnej działalności proboszcza mogą być różne i przykładowo zostały wyliczone w kan. 1741: 1) sposób postępowania, który przynosi kościelnej wspólnocie poważną szkodę lub zamieszanie; 2) nieudolność albo trwała choroba umysłowa lub fizyczna, która czyni proboszcza nieużytecznego w wypełnianiu jego zadań; 3) utrata dobrego imienia u uczciwych i poważnych parafian lub niechęć w stosunku do proboszcza, które według przewidywania szybko nie ustaną; 4) poważne zaniedbanie lub naruszenie obowiązków parafialnych, które trwa mimo upomnienia; 5) złe zarządzanie dobrami doczesnymi, z wielką szkodą Kościoła, ilekroć na zaradzenie złu brak innego środka.

Oczywiście wymienionych powodów nie powinno traktować się w sposób taksatywny. Określenie „Zwłaszcza następujące” sugeruje, iż nie stanowią one katalogu zamkniętego. Zapis kanonu powinno się również 
odczytywać w szerszym kontekście normatywnym. Ustawodawca w kan. 1740 zaznacza, iż taka możliwość istnieje, kiedy pojawią się ,jakieś przyczyny". Owe przyczyny powinny występować przeciw temu wszystkiemu, co związane jest z urzędem proboszcza. Nie można jedynie poprzestać na przyczynach zawartych w kan. 1741, bo z pewnością nie tylko one występują przeciw wykonywaniu przez proboszcza funkcji nauczania, kierowania i uświęcania, a których ocena zawsze pozostaje wyłączną kompetencją biskupa diecezjalnego, który decyduje o wszczęciu procedury usunięcia proboszcza. Należy zaznaczyć, że nie chodzi tu o jakiekolwiek przyczyny, ale o przyczyny poważne, o czym stanowi kan. $193 \S 1 \mathrm{KPK} / 83$, na który również powołuje się Dekret w art. 42 pkt $4 \mathrm{w}$ kontekście zaostrzenia kary. W analizowanej procedurze nie wymaga się, aby proboszcz popełnił jakiekolwiek przestępstwo, lecz wystarczy jedynie zachowanie, które w pewnym stopniu może zaważyć na właściwym wypełnieniu posługi. Taka sytuacja może mieć miejsce nawet bez poważnej winy ze strony proboszcza, co w wypadku przetwarzania danych jest wielce prawdopodobne. Dodatkowo przyczyna zmierzająca do usunięcia proboszcza musi mieć charakter trwały, w innym bowiem przypadku, biskup może zaradzić zaistniałej sytuacji mianując na określony czas administratora parafii, aby zadbać o posługę duszpasterską w parafii. Ostatnią cechą przyczyny umożliwiającej biskupowi wszczęcie procedury usunięcia, jest jej udowodnienie. W wypadku, gdyby zaistniał fakt braku przyczyny, lecz tylko prawdopodobieństwo, czy błędne o niej przekonanie, proboszcz może prosić o odwołanie dekretu, a ostatecznie wejść na drogę rekursu przeciw dekretowi biskupa diecezjalnego (kan. 1737 § 1) [Gałkowski 2012, 91].

Dekret w ramach przewidzianych sankcji za niewłaściwe przetwarzanie danych w art. 42 stanowi: „1) Kto powoduje szkody materialne lub moralne poprzez nieuprawnione pozyskanie, przechowywanie i wykorzystywanie danych osobowych jest zobowiązany do naprawienia szkody zgodnie z kan. 128 Kodeksu Prawa Kanonicznego oraz kan. 935 Kodeksu Kanonów Kościołów Wschodnich; 2) Karze przewidzianej przez kan. 1389 Kodeksu Prawa Kanonicznego oraz kan. 1464 Kodeksu Kanonów Kościołów Wschodnich podlega ten, kto naruszając niniejsze przepisy 2.1) nadużywa władzy kościelnej lub urzędu, 2.2) dokona lub zaniecha bezprawnie z powodu zawinionego zaniedbania aktu władzy kościelnej lub aktu urzędowego powodując szkodę dla innej osoby; 3) Karą przewidzianą w kan. 1390 $\S 2$ Kodeksu Prawa Kanonicznego oraz kan. 1452 Kodeksu Kanonów 
Kościołów Wschodnich może zostać ukarany ten, kto nie zachowując niniejszych przepisów narusza czyjeś dobre imię; 4) Jeżeli przestępstwo polega na naruszeniu obowiązku służbowego kara podlega zaostrzeniu i może także polegać na odwołaniu lub na pozbawieniu urzędu zgodnie z kan. $193 \S 1$ i $3 ; 196 \S 1 ; 1336 \S 1$, n. 2 i 1389 Kodeksu Prawa Kanonicznego oraz kan. 975 § 1 i 2; 978; 1464 Kodeksu Kanonów Kościołów Wschodnich".

Analizując przepisy prawne dotyczące usunięcia proboszcza zawarte w KPK/83, jak również przepisy Dekretu można stwierdzić, że biskup diecezjalny po zaistnieniu określonych przesłanek może wszcząć procedurę usunięcia proboszcza. Urząd kościelny, w tym posługa proboszcza, jeżeli działa na szkodę wspólnoty lub przynajmniej jest nieskuteczna, nie może pozostać bez reakcji biskupa, który ponosi odpowiedzialność pasterską za powierzoną diecezję. Proboszcz jako podmiot przetwarzający dane w imieniu parafii, która jest ich administratorem, w ramach pełnionego urzędu, zobowiązany jest do przestrzegania właściwej kultury przetwarzania danych, jak również stosowania przepisów wynikających z prawa powszechnego, jak i specjalnego (por. rozdz. II Dekretu, zwłaszcza art. 6-9; rozdz. III Dekretu). Ponadto jest zobowiązany do wdrożenia właściwych środków technicznych i organizacyjnych oraz przestrzegania przepisów dotyczących przechowywania, dozwolonego użytku i właściwego zarządzania danymi osobowymi (art. 17 Dekretu).

Analizując powyższe uwagi, jeżeli postępowanie proboszcza przynosi szkodę Kościołowi lub „dobru dusz”, biskup może podjąć decyzję o usunięciu proboszcza. Do przesłanek, które mogłyby być podstawą dla takiego działania w zakresie administrowania danymi parafii przez proboszcza są: 1) bezpodstawne naruszenie dobrego imienia osoby lub naruszenie prawa osoby do ochrony własnej intymności (kan. 220); 2) masowy wyciek danych z parafii, czego można było uniknąć przez wdrożenie odpowiednich środków zabezpieczających, a co przyniosło dużą szkodę dla wiernych; 3) jeżeli proboszcz nie zastosował się do czynności i zadań koniecznych w zakresie dokumentacji, procedur i zabezpieczeń wskazanych przez kościelnego inspektora ochrony danych jako konieczne i nie wdrożył odpowiedniej polityki bezpieczeństwa, jeżeli nie wymagałoby to dużego nakładu ze strony parafii.

Oczywiście biskup nie jest zobowiązany do wszczęcia procedury w każdym przypadku (kan. 1741). Jeżeli konieczność tego nie wymaga, biskup 
może zaradzić określonej sytuacji przez upomnienie czy wymierzenie nagany, lub polecić wypełnianie obowiązków wikariuszowi lub takiego na pewien czas mianować. Jeżeli proboszcz naprawi zaistniałą sytuację w sposób właściwy i nie pozostanie ona trwała, wtedy wspomniane środki mogą być wystarczające.

Jeżeli natomiast biskup stwierdzi, że należy wszcząć procedurę usunięcia, należy bezzwłocznie do niej przystąpić. Aby decyzja biskupa mogła być skuteczna, prawodawca podaje dla niej określone warunki: 1) przyczyna musi być poważna i trwała, 2) biskup musi wysłuchać opinii dwóch proboszczów należących do zespołu wyłonionego na stałe z rady kapłańskiej, 3) podanie w dekrecie przyczyn i argumentów (kan. 1742 § 1).

Biskup diecezjalny, do ważności dalszej procedury, jest zobowiązany do wysłuchania opinii dwóch proboszczów. Jednak dla lepszego zapoznania się z zaistniałą sytuacją i poznania faktów i opinii, może sprawę również skonsultować z innymi kapłanami z rady kapłańskiej, a także z dziekanem, kapłanami współpracującymi z proboszczem i innymi osobami. W procedurze, gdzie przyczyną jest naruszenie właściwego przetwarzania danych przez proboszcza, bardzo pomocna może być opinia inspektora ochrony danych $\mathrm{w}$ diecezji, jak również, jeżeli z przyczyny, przez którą proboszcz ma być usunięty, pozostają konsekwencje prawne zgłoszenia sprawy Kościelnemu Inspektorowi Ochrony Danych, czy Prezesowi UODO, również opinia Kościelnego Inspektora Ochrony Danych, który pełni funkcję urzędową w rozumieniu kan. 145 KPK/83 (art. 35, pkt 2 Dekretu). Taka opinia byłaby nieodzowna szczególnie w sytuacji naglącej, kiedy inne środki zaradcze nie skutkują, a procedurę usunięcia kontynuuje np. nowo mianowany biskup diecezjalny.

\section{PODSUMOWANIE}

Podsumowując powyższą analizę należy zaznaczyć, że biskup diecezjalny posiada określone przez prawo środki nadzoru i kontroli nad administratorami danych we własnej diecezji. Co do zasady są to sprawy wyłącznie objęte misją Kościoła i są wykonywaniem wewnętrznych zadań Kościoła objętych, w większości przypadków, prawem kanonicznym.

Najbardziej powszechnym administratorem danych w diecezji jest parafia, gdzie podmiotem przetwarzającym dane jest $\mathrm{z}$ zasady proboszcz. To 
jednostka parafialna jest zobligowana do przestrzegania przepisów dotyczących właściwego przetwarzania danych zarówno w zakresie wewnętrznym, jak również mieszanym (kościelno-państwowym), dlatego zostały wymienione i zaproponowane środki kontroli i nadzoru (szczególnie przy okazji określonych wizytacji kanonicznych) dla przestrzegania właściwej kultury przetwarzania, jakimi dysponuje biskup we własnej diecezji. W sytuacjach koniecznych w związku z niewłaściwym sposobem przetwarzania biskup posiada narzędzia, aby chronić dobro wspólnoty Kościoła, do wszczęcia procedury usunięcia proboszcza. Warto również pamiętać, że słowo dyscyplina pochodzi od łac. discipulus, tzn. uczeń, a zatem każdy sposób dyscypliny, nadzoru i kontroli staje się szansą dla wzajemnego pouczenia, by lepiej służyć wspólnocie Kościoła i chronić dobre imię każdego człowieka (kan. 220).

\section{PIŚMIENNICTWO}

Banaszak, Bogusław. 2012. Konstytucja Rzeczypospolitej Polskiej. Komentarz. Warszawa: Wydawnictwo C.H. Beck.

Gałkowski, Tomasz. 2012. „Usunięcie proboszcza. Analiza konkretnego przypadku.” Łódzkie Studia Teologiczne 21:89-98.

Gambari, Elio. 1995. Życie zakonne po Soborze Watykańskim II. Kraków: Wydawnictwo Karmelitów Bosych.

Jougan, Alojzy. 1992. Stownik kościelny tacińsko-polski. Sandomierz: Wydawnictwo Diecezjalne Sandomierz.

Krukowski, Józef. 2008. Polskie prawo wyznaniowe. Warszawa: Wolters Kluwer Polska.

Paolis, Velasio. 2010. La vita consacrata nella Chiesa (edizione rivista e ampliata a cura di Vincenzo Mosca). Venezia: Marcianum Press.

Pawluk, Tadeusz. 2010. Prawo kanoniczne wedtug Kodeksu Jana Pawła II. T. 2: Lud Boży jego nauczanie i uświęcanie. Olsztyn: Warmińskie Wydawnictwo Diecezjalne.

Pawluk, Tadeusz. 2016. Prawo kanoniczne wedtug Kodeksu Jana Pawła II. T. 4: Dobra doczesne Kościoła. Sankcje w Kościele. Procesy. Olsztyn: Warmińskie Wydawnictwo Diecezjalne.

Sondel, Janusz. 1997. Stownik łacińsko-polski dla prawników i historyków. Kraków: Wydawnictwo Universitas.

Sztafrowski, Edward. 1992. „Ponadparafialni współpracownicy biskupa diecezjalnego.” Prawo Kanoniczne 35, nr 3-4:25-56.

Zubert, Bronisław W. 1990. Komentarz do Kodeksu Prawa Kanonicznego z 1983 r. T. 2. Cz. 3: Księga II. Lud Boży. Część III. Instytuty życia konsekrowanego $i$ stowarzyszenia życia apostolskiego. Lublin: Redakcja Wydawnictw KUL. 


\section{Nadzór i kontrola biskupa diecezjalnego nad administratorami danych w diecezji (analiza na podstawie przykładu parafii)}

\section{Streszczenie}

W rozważaniach dotyczących nadzoru i kontroli biskupa diecezjalnego nad administratorami danych $\mathrm{w}$ diecezji należy stwierdzić, iż posiada on określone środki prawne, aby w sposób skuteczny dbać o właściwą kulturę przetwarzania danych osobowych, zwłaszcza w strukturach parafii. Służą mu do tego narzędzia wizytacyjne oparte w przepisach Kodeksu Prawa Kanonicznego, jak również osoby do tego wyznaczone. W przypadku niewłaściwego przetwarzania danych przez parafię, biskup diecezjalny ma możliwość wszczęcia procedury usunięcia proboszcza, aby przeciwdziałać szkodzie wspólnoty parafialnej.

Słowa kluczowe: ochrona danych; inspektor; nadzór; wizytacja parafii; usunięcie proboszcza

\section{Supervision and Control of the Diocesan Bishop over Data Administrators in the Diocese (Analysis Based on the Example of a Parish)}

\section{Summary}

When considering the supervision and control of the diocesan bishop over the data administrators in the diocese, it should be stated that he has specific legal means to effectively care for the proper culture of personal data processing, especially in the parish structures. For this purpose, he uses visitation tools based on the provisions of the Code of Canon Law, as well as persons designated to do so. In the event of improper processing of data by the parish, the diocesan bishop has the possibility to initiate the procedure of removing the parish priest to prevent harm to the parish community.

Key words: data protection; inspector; supervision; parish visit; removal of the parish priest

About the Author: Rev. Maciej KoŁodZiejski, Ph.D. STUdent - Doctoral School, the Cardinal Stefan Wyszyński University in Warsaw; e-mail: kmaciu@wp.pl; https:// orcid.org/0000-0002-8972-2709 